\title{
JUDGE AS CONSCIENTIOUS OBJECTOR - ANALYSIS BASED ON CULTURAL EXEMPTIONS THEORY AND U.S. LAW ${ }^{1}$
}

\author{
Szymon Mazurkiewicz*
}

Keywords: conscience clause of a judge, conscientious objection, exemption theory, judicial disqualification, judicial bias, right to fair trial

Abstract: The aim of this paper is to analyze whether it is possible for a judge to possess the right to conscientious objection. Firstly, the author provides some conceptual remarks along with distinguishing conscientious objection from other situations concerning conflict between law and morality that involve judges. Next, cultural exemptions/religious accommodations theory is introduced as a conceptual basis for further analysis. W. Ciszewski's multidimensional view on exemption theory is applied here. It distinguishes three levels of discussion: the general legitimatization of accommodations, secondly, the justification of a concrete exemption and thirdly the scope,

1 The second part of this paper, dedicated to exemption theory and its application into the analysis of the justifiability of a judge's conscientious objection, is similar to considerations from one section of my paper Klauzula sumienia sędziego? - analiza z zakresu filozofii politycznej, filozofii prawa oraz prawa pozytywnego [Judge's conscience clause? - Analysis from the scope of Political Philosophy, Philosophy of Law and Positive Law], [in:] 'Prawo - polityka - sfera publiczna' (in preparation). After the analysis of general issues from political philosophy and the philosophy of law, the author of the aforementioned paper discussed the Polish legal system perspective, whereas here the focus is on the U.S. legal order with some remarks on international human rights law.

* PhD student, Jagiellonian University, Faculty of Law and Administration, Department of Law Theory 
process of application and exclusions of the specific exemption. This paper involves the second level and some issues from the third. Five premises given by W. Ciszewski are considered: (1) significance of a goal realized by regulation, (2) formal amenability of a duty to exclusion, (3) significance of one's world view being in conflict with duty, (4) prohibition of the unjustified privileging of a group and (5) size of a group that may obtain an exemption. The last part involves the problem of applying a conscience clause. In the paper the author analyzes whether the regulation of judicial disqualification, especially judicial recusal, can be regarded as a legal basis for taking advantage of conscientious objection. The author also considers the boundaries of the clause of conscience with special emphasize on the individual's right to a fair trial.

\section{Introduction}

Consider a situation as follows: in a legal system that allows the death penalty there is an accused that under all evidence and legal reasoning should be sentenced to death. Another penalty would be unfair and contradictory to some legal regulations. However, a judge that is going to reach a decision in this case could be a member of a religious group that strongly prohibits the death penalty and finds everyone who has been connected to the death sentence as a murderer. What should the judge do? Deciding the case in the only possible way is in conflict with his conscience. On the other hand, another sentence would be both illegal and regarded as iniquitous by the majority of society. Does the judge have any good possibility of conduct? Most judges all over the world seem to be committed to the 'sit doctrine', which claims that they have to reach a decision in every filed case unless some very specific circumstances occur. ${ }^{2}$ However, why not allow judges not to reach a decision in such a case on the basis of the same principles that allow some persons to resign from military service or allowing Sikhs to ride a motorcycle without a helmet? This would mean that judges have the right to conscientious objection.

The aim of this paper is to analyze whether it is possible for a judge to possess the right to conscientious objection, which can also be referred

2 J. Stempel, Chief William's Ghost: The Problematic Persistence of the Duty to Sit Doctrine, 'Scholarly Works' 2009, Paper 232, p. 1, passim. 
to as the conscience clause. It needs to be distinguished from judicial disobedience. While judicial disobedience leads to passing a judgment, often contra legem but in accordance with moral standards, ${ }^{3}$ application of judicial conscientious objection will result in denial of any judgment. After some conceptual remarks, the first part of the paper will involve an analysis based on political philosophy. It will be an analysis of the moral justification of a judge's conscientious objection. However, the recognition of the philosophical and moral grounds for a judge's objection will not automatically lead to the possibility of its legal application. Thus, the second part of the paper will involve an analysis based on positive law, especially on the institution of judicial recusal under U.S. legal system, in order to find the proper legal basis for the application of a judge's conscientious objection.

The conscientious objection has its roots in the denial of military service. It has also been discussed in some cases concerning the medical services. Nowadays, the discussion has involved increasingly more occupations and situations, for instance pharmacists. ${ }^{4}$ Thus, there is no reason not to consider whether a judge may have the right to conscientious objection. A judge, on the one hand, is obliged to obey the law and apply regulations that bind him. However, he has the same rights as a Sikh citizen on a motorcycle or a Muslim who does not work on Fridays, with the same rights to conduct in accordance with his conscience. However, he also wields judicial power, and the participants of a judicial litigation have a right that the case be decided according to law, and not according to only a judge's conscience as an individual. Therefore, what should a judge do when a case that he is to make a decision on is contrary to his conscience? A judge's right to conscientious objection could be a solution. It can be defined as a judge's right not to reach a decision in a case if the case itself or its outcome is in conflict with the judge's moral beliefs. Notwithstanding, we have strong intuition that a judge must reach a decision in every case and cannot simply choose which cases he wants to decide and which he does not. The author hopes to resolve the above dilemmas below.

3 J. Zajadło, Nieposłuszeństwo sędziowskie [Judicial Disobedience], 'Państwo i Prawo' 2016, no. 1, p. 18, at p. 32.

4 J. Miller, The Unconscionability of Conscience Clause: Pharmacists' Conscience and Women's Access to Contraception, 'Health Matrix: The Journal of Law-Medicine' 2006, vol. 16, no. 1, p. 237, pp. 238-239; M. Collins, Conscience Clause and Oral Contraceptives: Conscientious Objection or Calculated Obstruction?, 'Annals of Health Law' 2006, vol. 15, no. 1, p. 37, pp. 37-38; D. Flynn, Pharmacists conscience clause and access to oral contraceptives, 'Journal of Medical Ethics' 2009, vol. 34, no. 7, p. 517, pp. 517-518. 


\subsection{Some conceptual remarks}

The conflict of a judge's belief and the case that he is to reach a decision upon may involve several situations. The following enumeration is not an empirical study, but rather a speculative form of analysis. Firstly, being occupied with a case itself can be in conflict with his conscience. Consider moral rule prohibiting any contact with something being evil in some religions. For instance, for a devout Catholic judge deciding on a case in which an abortion clinic claims its civil debts, having nothing in common with the abortion service, can be in conflict with his religious beliefs. Secondly, the outcome of a case given properly according to the legal reasoning can be contradictory to a judge's conscience. The hypothetical Catholic judge could also be loathe to mete out the death penalty in jurisdictions where it is applied. Next, some outcomes of the case, which are possible under legal reasoning, can be in conflict with a judge's beliefs. This might mean a judge can only give decision $\mathrm{A}$ or $\mathrm{B}$, while decisions $\mathrm{C}$ and $\mathrm{D}$, being proper from the legal point of view, would not be possible for him from a moral point of view.

A judge's conscience clause needs to be distinguished from other situations concerning a judge and some kind of conflict with morality. Firstly, when discussing conscientious objection we are discussing only one's individual conscience and moral beliefs. Considering the general role of morality in legal decision making, especially judicial, would lead to analyzing issues from general jurisprudence, as whether morality is a necessary component of law or if morality may or even should be taken into consideration while reaching a decision in cases. ${ }^{5}$ These are extremely important issues, however the concept of morality which they use is the general morality of a society, that is morality which everyone or almost everyone shares. Nonetheless, in conscientious objection we have a situation when a legal obligation is contrary to only an individual's moral beliefs. Of course, these moral views can be a part of a larger moral system, which is shared by a wide range of people. Moreover, this moral belief can be a part of a moral system prevailing in a society. However, this does not matter. What is important here is the conscience of the individual. Therefore, any answer to the question of the possibility of possessing

5 G. Postema, Legal Philosophy in the Twentieth Century: The Common Law World, 'A Treatise of Legal Philosophy and General Jurisprudence', vol.11, Springer, Dodrecht, Heidelberg, London, New York 2011, p. 4, pp. 325-326. 
the right to conscientious objection by a judge would not lead to any statement on the general role of morality in the concept of law or theory of adjudication.

Secondly, a conscience clause is always the right not to fulfil one's legal duty. In the analyzed issue, the obligation of a judge is to reach a decision in every case that is submitted. Therefore, the application of the right to conscientious objection would never lead to the delivery of a judgment. It distinguishes conscientious objection from other situations where a judge does not want to reach a decision in a case according to legal rules, but decides it based on moral standards. Here, it would be unacceptable since the right to conscientious objection is prevalently possessed or used by minorities, which would lead to situations when cases would be decided on the basis of a moral system that is shared by some minority in a society. Thus, a judge's conscientious objection is different from judicial disobedience, where a judge reaches a decision in a case, but contra legem (however, in accordance with moral standards). ${ }^{6}$ A hypothetical judicial conscience clause would never lead to a judgment being passing.

\section{Theory of religious exemptions (cultural accommodations)}

A judge's conscientious objection and conscientious objection in general can be discussed within a broader theory of religious exemptions (cultural accommodations). ${ }^{7}$ This theory has its roots in political philosophy, especially liberal philosophy. These accommodations/exemptions are regulations allowing an individual not to fulfil some general duty in virtue of their world-view or for cultural reasons. J. Levi defines them as: "individually exercised negative liberties granted to members of a religious or cultural group whose practices are such that a generally and ostensibly

$6 \quad$ J. Zajadło, op. cit., p. 32.

7 J. Waldron, One Law for All? The Logic of Cultural Accommodation, 'Washington and Lee Law Review' 2002, vol. 59, no. 1, p. 3; J. Quong, Cultural Exemptions, Expansive Tastes and Equal Opportunities, 'Journal of Applied Philosophy' 2006, vol. 23, no. 1, p. 53; P. Bou-Habib, A Theory of Religious Accommodation, 'Journal of Applied Philosophy' 2006, vol. 23, no. 1, p. 109. 
neutral law would be a distinctive burden on them". ${ }^{8}$ This theory includes not only traditional examples of exemptions as conscientious objection in the military or medical services but also gives background to discussing a new one.

According to W. Ciszewski, the whole process of discussing exemptions may be split into three dimensions. Firstly, the general legitimatization of accommodations, secondly, the justification of a concrete exemption, thirdly the scope, process of application and exclusions of this specific exemption. ${ }^{9}$ I will omit arguments for exemptions in general. Many papers focus on the general legitimization of cultural accommodations and problems being involved, ${ }^{10}$ my aim is however to analyze the justifiability of one specific exemption. The author's intention is to analyze the second and third step here - the possibility of the legitimization of a judge's objection with its limitations and the way they are applied. In the broad literature on the theory of exemptions several main premises can be distinguished for the analysis of the justification of a concrete exemption. Later in this paper, we will take advantage of W. Ciszewski five-dimensional process of analyzing justifiability of a concrete exemption. He proposes the following levels of analysis: (1) significance of a goal realized by regulation, (2) formal amenability of a duty to exclusion, (3) significance of one's world view rule being in conflict with duty, (4) prohibition of unjustified privileging a group and (5) size of a group that may obtain an exemption. ${ }^{11}$ For W. Ciszewski these are the most important factors of consideration in exemption theory. Among the English literature, the first four can be found in J. Qoung's work, ${ }^{12}$ the last is present in the work of K. Vallier. ${ }^{13}$ In the next part of the paper, we will analyze whether a judge's conscientious objection fulfils each of the requirements.

8 J. Levy, The Multiculturalism of Fear, Oxford University Press, Oxford 2000, p. 1, at p. 128.

9 W. Ciszewski, Wyłączenia światopoglądowe jako przedmiot dyskusji teoretycznej próba systematyzacji . [Cultural Exemptions as Object of Theoretical Discussion - Attempt at Systematization], 'Forum Prawnicze' 2016, vol. 34, no. 2, p. 59, p. 60.

10 W. Ciszewski, op. cit., pp. 61-64; J. Waldron, op. cit., passim; J. Quong, op. cit.; passim.

11 W. Ciszewski, op. cit., pp. 65-68.

12 J. Quong, op. cit., pp. 61.

13 K. Vallier, The Moral Basis of Religious Exemptions, 'Law and Philosophy' 2016, vol. 35 , no. 1 , p. 1 , pp. 15-16. 


\subsection{Significance of a goal realized by regulation}

In the first criterion W. Ciszewski proposes the importance of a general regulation that should be excluded. The more regulation is important, the lesser the demand for some exemption. ${ }^{14}$ Here, we should look at the function of obligation which an individual is going to obtain exemption from. J. Quong writes: "The practice must not violate any basic rights or principles of justice". ${ }^{15}$ As an example, this importance of an obligation standard seems to lead to the lack of conscientious objection for military service in South Korea. In a country continually threatened with nuclear conflict, the role of military service is so important for the country's safety that no exemption is possible. ${ }^{16}$

How does this fit into our analysis? The author believes the obligation that is to be excluded is a judge's duty to reach a decision in every case submitted to the court. The function of this duty is to guarantee every individual that his case will be decided impartially by an independent court. It should be stressed that the obligation to be excluded cannot be a human and basic right to a fair trial. This rule is of such importance that it can never be excluded. The obligation to reach a decision in every case and the function that it realizes is of course extremely important, however the acceptance of exclusions seems possible. It is worth noting that these exclusions are present in every legal system in the regulation of judicial disqualification, when under specific circumstances, for example being related to a litigant party or in a case involving the judge's interest, the judge has to be disqualified from reaching a decision in the case. It is therefore not true that the obligation to reach a decision in every case does not contain exclusions. In fact, judicial disqualification is a regulation that helps preserve the principle of impartiality. One can assume that there may be other situations, which could give rise to serious concerns about the impartiality of a judge. Could not this be a situation when a case is in conflict with a judge's conscience and a judge is not able mentally to reach a decision in a case only on the basis of legal rules? The author thinks that the judge's conscientious objection fulfils the first dimension of the analysis. Although the obligation to reach a decision in every case

14 W. Ciszewski, op. cit., p. 65.

15 Quong, op. cit., p. 58.

16 Is South Korea thawing to conscientious objection?, 'The Korea Herald', 19.12.2016. 
and its function is important, it can include exclusions. One of them might be the judge's conscientious objection.

\subsection{Formal amenability of a duty to exclusion}

The second level of analysis is the vulnerability of a regulation to obtain exclusions. While the first dimension involves some material element and substantial value, the second focuses on a formal possibility. ${ }^{17}$ J. Quong writes: "Laws about which side of the road we can drive on, for example, are not amenable to exemptions, whereas laws regulating uniforms for military and police officers are" ${ }^{18}$ Any, even a single, exemption from the first would lead to the destruction of the whole rule assigning on which side of the road we can drive. For the second, it would not. It is debatable whether the dimensions of analyzing the justifiability of an exemption are rules or standards in Dworkin's terms. ${ }^{19}$ However, it is without any doubt clearly seen that this second criterion is a rule. It cannot be measured under formula of weight and can be only fully fulfilled or not fulfilled at all.

The above-mentioned legal regulation of judicial disqualification indicates directly that the obligation to reach a decision in every filed case is amenable to exemption. Again, if the analyzed duty were not a judge's but a tribunal obligation to reach a decision in every case (as a reflection of the individuals' subjective right to tribunal), considerations of the possibility of exemption would fall on this point. This is such a significant standard that even a single exclusion would lead to the destruction of the whole possibility of taking advantage of the basic right to tribunal.

\subsection{Significance of one's world view rule being in conflict with duty}

Now, consideration touches upon one of the most controversial levels of analysis. It involves the analysis of the importance of a belief in someone's

17 W. Ciszewski, op. cit., p. 66.

18 Quong, op. cit., p. 61.

19 R. Dworkin, Taking Rights Seriously, Harvard University Press, London 1977, p. 1, p. 22 . 
world-view. J. Qoung notes: “The more central the practice is, the stronger the claim for exemption becomes". ${ }^{20}$ However, it is not debatable whether one's conscience can be judged in order to allow an accommodation. As proponents of this dimension argue, reasonable religious or cultural beliefs should be distinguished from simply preferences. ${ }^{21}$ Only the first can justify exemption.

For a judge's conscientious objection it is practically impossible to give an answer based on this criterion. In contrast to the vast majority of present accommodations, a judge's conscientious objection would involve a potentially endless number of cultural rules standing in contradiction to the submitted case and an even endless number of cases which could be in conflict with one's beliefs. For some groups, possible moral beliefs leading to objections can be easily demonstrated. For instance, for a Catholic judge it could be morally impossible to give consent for an abortion (under some legislations such consent is required in rare and specific situations) ${ }^{22}$ or to reach a decision in divorce cases. For a member of some religious group it could be impossible to sentence someone to death. However, the more society is diverged, the more difficult it is to give such a specific situation. Notwithstanding, the issue of such broad possibilities, in which a judge's conscientious objection could be applied, is a problem of the manner of applying a specific accommodation, which is another issue than its general justifiability.

\subsection{Prohibition of unjustified privileging a group}

J. Quong names the last of his four factors as consideration within the idea of fairness, however, in my view, W. Ciszewski expresses the core of this dimension in a better way as a prohibition of unjustified privileging a group. ${ }^{23}$ It includes analysis if a new exemption does not introduce more unjustness to society than its lack. Thus, for instance, a special specification of holidays must not entail less work for the entitled group.

20 Quong, op. cit., p. 61.

21 W. Ciszewski, op. cit., p. 67.

22 Article 4a(4) of Polish law of family planning, protecting the human foetus and the conditions of admissibility of pregnancy termination, Polish OJ 1993, No. 17, Item 78 with further changes.

${ }^{23}$ W. Ciszewski, op. cit., p. 67. 
In this case, if judges from a group that factually takes advantage of objection actually had fewer cases to decide it would be unfair and such an exemption could not be allowed. This dimension is more matter of fact than some general normative reasoning, therefore, similar to the previous point, a general answer cannot be given. However, some inconclusive thoughts can be given. We can imagine a division of a court in which numerous cases might be contradictory to a large group of judges of this division. It could be a Polish family division which decides divorce cases or, in countries having the death penalty, a criminal division. If a significant group of judges were objectors, the rest of them would have to reach a decision in many more cases. A solution might be not to sit in such a division for judges whose conscience might be in conflict with certain types of cases. However, it should be undertaken before beginning a case and necessary legal regulations would also be needed here.

\subsection{Size of a group that may obtain an exemption}

The last dimension is not proposed by Quong but it can be met in the discourse. ${ }^{24}$ Generally, the larger a group, the lesser is their demand for an accommodation. If most of society demanded an exemption, why should we be committed to the present version of a legal regulation and not simply alter the law in order for the postulated exemption to become a generally binding rule?

Transferring this factor into the analysis of the legitimization of a judge's conscientious objection touches again upon factual matters. However, this point of analysis is doubtful. Consider such a situation. There is a legal regulation that obliges everyone to wear a helmet while riding a motorcycle. It also says that members of religious groups that call for them to wear religious head attire in public is allowed not to wear a helmet. Assume next that there is a society where $90 \%$ of citizens are members of such groups and they do not wear a helmet. Reversing a regulation, and allowing everyone not to wear a helmet seems not to violate any principle of justice. However, notice a different situation. Under some regulations, doctors are allowed not to perform some services if they are contradictory to their beliefs. In some countries, $90 \%$ of doctors could take advantage of this clause and not perform some services. Our intuitions distinguish

${ }^{24}$ W. Ciszewski, op. cit., p. 68; K. Vallier, op. cit., pp. 15-16. 
these two cases. In the first, exemption does not violate any other person's rights. In the latter, until a few doctors apply the clause, it also does not. However, when the group become larger the situation changes. Citizens can be factually deprived of their rights to some medical services.

The judge's conscience clause is similar to the second situation. If a large group of judges took advantage of their right to objection, citizens could be deprived of the right to a tribunal. Despite the fact that there would be valid legal regulations, in fact, they could not be enforceable. Such a situation is impermissible and a judge's conscience clause would not be justified in terms of exemption theory. However, it needs to be noted that this is more factual than general and a normative problem concerning the number of judges from a specific cultural or religious group. Thus, answers may differ depending on a society.

\section{Problem of individual's right}

Considerations based on five main factors existing in the theory of exemptions/accommodations do not prohibit a judge's conscientious objection. None of the criteria is used, however a new one should be added involving the role of a judge in the democratic legal system. As it has been said, taking advantage of the possibility for a Sikh to ride a motorcycle without a helmet would never violate another individual's rights. Many of the exemptions work just the same. However, the judge is not only an individual, he also wields judicial power and acts in the name of the State in his judicial responsibilities. Thus, a citizen's individual rights need also be taken into consideration. As it has been mentioned previously, taking advantage of a judge's conscientious objection can never lead to violating the basic right to tribunal. There are a several important factual features involved following this idea. They are connected with a situation when a judge's conscientious objection is generally justified, also in the light of the size of the group that could obtain exemption. Here, we touch upon detailed particular issues.

A judge's conscientious objection can never lead to the factual closing of the possibility for a tribunal to decide a case. Thus, when a case can be decided only by some period and taking advantage of a judge's conscientious objection would lead to a delay causing the new judge not to have enough time to reach a decision in the case, a judge must not take advantage of conscientious objection and should reach a decision 
in the case. The author believes that in such a situation the individual subjective right prevails over a judge's conscience. The issue of the proper period can involve both purely legal aspects as a limitation period and situations when the principle of deciding a case in reasonable time could be violated. No judge's belief can block anyone's right to tribunal, which is a basic human rights prescribed by international human rights law. ${ }^{25}$

To conclude, a judge's conscientious objection is generally justified in terms of exemption theory. It should be however emphasized that some premises that have been analyzed here involve also factual issues, where social facts of a given society play a much more important role than normative analysis. In this scope, a general conclusion is difficult to give and answers concerning the justifiability of a judge's conscientious objection may differ in different societies.

\section{Basis of the application of the judge's conscientious objection}

Ascertaining the philosophical justifiability of the judge's conscientious objection is one thing, finding the proper legal basis of its application is another. Each judicial decision must be conducted in accordance with valid law. On the other hand, freedom of religion and conscience are one of the basic human rights and a judge is also their holder. However, the character in which a judge can have the right to conscientious objection may be highly contested. The author believes two possible notions can be distinguished. In the first, the conscience clause would be attributed to a judge as a State organ. In the second, the judge as an individual, like every other person, would possess the right to conscientious objection. Such a distinguishing feature seems to be compatible with the discussion among judges in the Baka v. Hungary European Court of Human Rights case. ${ }^{26}$ In short, the case involved a situation when Mr. Baka's role as President of the Hungarian Supreme Court and simultaneously President of the National Council of Justice was terminated in virtue of establishing

25 Universal Declaration of Human Rights, 1948, Article 10; European Convention on Human Rights, 1950, Article 6; International Covenant on Civil and Political Rights, 1966, Article 14.

${ }^{26}$ Baka v. Hungary, Application no. 20261/12, Judgment of 23.06.2016, ECHR 2016-III 
a new constitution. There was however no judicial control of this termination. The European Court of Human Rights delivered a judgment in which it held that there had been a violation of Articles 6(1) and (10) of the Convention. What is important for the analysis of the judicial objection is that Mr. Baka, whose rights had been violated, was State official and wielder of judicial power. Thus, it is worth recalling the discussion between Judge Sicilianos and Judge Wojtyczek concerning who is the holder of human rights. Sicilianos in a concurring opinion claims:

In my opinion, however, the rule of law is hardly imaginable without an obligation on the State to offer safeguards for the protection of judicial independence and, hence, without the corresponding right of judges themselves to independence. Moreover, as is clear from the entirety of the international-law materials cited in the present judgment, judicial independence is today an integral part of the general principles of international law which must be taken into account in interpreting the Convention. Equally, an interpretation of Article 6(1) which finds that it protects the judge's subjective right to independence would be perfectly compatible with that provision's object and purpose. In this connection, I subscribe to the idea, set out in the Magna Carta of Judges, to the effect that "judicial independence and impartiality are essential prerequisites for the operation of justice". Indeed, how can one hope that persons involved in court proceedings will enjoy the right to an independent judge if judges themselves are not afforded safeguards capable of ensuring that independence? In my opinion, a subjective right of this sort for judges is inherent in the safeguards of the first paragraph of Article 6, and in the concept of a fair hearing. ${ }^{27}$

For Sicilianos, judicial impartiality is a part of the public law principle of independence of tribunals. It cannot be preserved without judges' right to independence as individuals. Sicilanos claims that the fact that one is a judge does not deprive him of the capability of being the holder of human rights while exercising official duties. Judge Wojtyczek, opposed to such arguments, filing dissenting opinion:

An individual is a holder of rights and duties in his or her relationship with the State. A State organ cannot be a holder of rights. Its status is analyzed in terms of its tasks and powers, as well as its interactions 
with other State organs. Acts performed in an official capacity cannot fall within the ambit of guaranteed rights. ${ }^{28}$

For Wojtyczek, the judge, in the scope of his judicial duties, is not entitled to the rights and freedoms included in the European Convention on Human Rights since he exercises public authority. A state organ cannot hold such a right, because it is always human right, even if this individual is a holder of State power and exercises official authority. As judicial conscientious objection has similar characteristics to judicial impartiality, this discussion can be useful in answering whether judicial conscientious objection is held by a judge as a State organ or rather as an individual. Following Sicilianos's thoughts, it would be held by a judge as an individual. On the other hand, accepting Wojtyczek's point of view, a judge would not be entitled to the right to conscientious objection at all, since while exercising public authority, he could not be a holder of human rights. The author cannot accept Wojtyczek's argumentation. The author believes that judicial conscientious objection would be a right of the judge as an individual. The judge himself, exercising official public duties is protected by norms respecting human rights, including conscientious objection. It is impossible to claim that a person only because of being a State official loses his human rights. It would violate the universal nature of human rights. Conscientious objection is meant as a means to be at peace with one's conscience and allow one to behave in accordance with one's moral beliefs in the public sphere. Such is also the role of judicial conscientious objection. It results also not in deciding a case by a judge who is not able to reach a decision in it only on a legal basis. Thus, its application guarantees the right to a fair trial by an independent tribunal. It is however a consequence of judicial conscientious objection, not its main function, though very important.

\subsection{Right to freedom of conscience in international human rights law}

It is possible to consider international human rights regulations as a legal ground for taking advantage of judicial objection. Freedom of religion, which includes also freedom of non-religious world-view beliefs is guaranteed by the First Amendment to the U.S. Constitution as well as

Baka v. Hungary, Dissenting Opinion of Judge Wojtyczek, supra note 26, para. 4. 
by article 9 of the European Convention on Human Rights. ${ }^{29}$ International treaties on human rights that are binding in the USA can be analyzed in their parts that talk about freedom of religion and freedom of conscience. The first to be mentioned, in article 18 of Universal Declaration of Human Rights, is:

Everyone has the right to freedom of thought, conscience and religion; this right includes freedom to change his religion or belief, and freedom, either alone or in community with others and in public or private, to manifest his religion or belief in teaching, practice, worship and observance. ${ }^{30}$

Despite the fact that Universal Declaration of Human Rights has been established only as a resolution of UN General Assembly, it is widely accepted that it has the binding legal force of international custom. ${ }^{31}$ Importantly, international customs are one of the sources of international law, ${ }^{32}$ which makes the force of Declaration the same as any international treaty.

Next, article 18 of the International Covenant on Civil and Political Rights says:

Everyone has the right to freedom of thought, conscience and religion. This right shall include freedom to have or to adopt a religion or belief of his choice, and freedom, either individually or in community with others and in public or private, to manifest his religion or belief in worship and observance, practice and teaching. ${ }^{33}$

With slightly different wording, the core aspect is the same as in Declaration. Also here we should prejudge that the right to freedom of thought, conscience and religion includes right to conscientious objection. The International Covenant is a treaty and has been ratified by the U.S.A. However, section 3 needs to be mentioned. It says:

29 U.S. Constitution, Amendment 1, 1791; European Convention on Human Rights, 1950, Article 9.

30 Universal Declaration of Human Rights, 1948, Article 18.

31 J. P. Humphrey, The Universal Declaration of Human Rights: Its History, Impact and Juridical Character, [in:] B. G. Ramcharan (ed.), 'Human Rights: Thirty Years After the Universal Declaration', Kluwer, The Hague-Boston-London 1979, p. 21, pp. 21, 37.

32 Statute of the International Court of Justice, Article 38.

33 International Covenant on Civil and Political Rights, 1966, Article 18(1). 
Freedom to manifest one's religion or beliefs may be subject only to such limitations as are prescribed by law and are necessary to protect public safety, order, health, or morals or the fundamental rights and freedom of others. ${ }^{34}$

Is it a basis for the possibility of establishing a prohibition of the conscience clause? Firstly, such a limitation would have to be prescribed by law. Secondly, a limitation would have to protect some value, the most probable would be public safety or another's rights, which would be the right to be judged by an independent and impartial tribunal. ${ }^{35}$ Also the necessity of such a limitation is required. The author believes both options of limitation cannot be satisfied. It is rarely inconceivable how several judges' rights not to reach a decision in some cases can violate public safety. The problem of the clash with another's rights has been analyzed in section 3 and here, and we can add only that such a situation is forbidden and the conscience clause cannot be applied if it might violate another's rights. It is worth noting how similar conclusions are made on the basis of international human rights law and the previous from the perspective of political philosophy and exemption theory. It is a point strongly ascertaining the philosophical part of these investigations.

However, although general analysis leads to the conclusion that international human rights law guarantees rights to conscientious objection, also judicial conscientious objection, it needs to be emphasized that it does not automatically mean that we can infer this to judicial conscientious objection as a human right as being valid in U.S. legal order. Firstly, the status of international law in the U.S. legal system is highly debatable. Since Medellin v. Texas it prevails among legal scholars that international treaties are less likely to be regarded as binding law. ${ }^{36}$ What is however much more important, is that the United States Senate has ratified the International Covenant on Civil and Political Rights with the following reservation: "the United States declares that the provisions of articles 1 through 27 of the Covenant are not self-executing". ${ }^{37}$ Thus, in practice

34 International Covenant on Civil and Political Rights, 1966, Article 18(3).

35 Universal Declaration of Human Rights, 1948, Article 10.

${ }^{36}$ P. R. Dubinsky, International Law in the Legal System of United States, 'The American Journal of Comparative Law', vol. 58, Supplement: Welcoming the World: U. S. National Reports to the XVIIIth International Congress of Comparative Law 2010, p. 455, at p. 461; Medellin v. Texas 552 U.S. 491 (2008).

37138 Cong. Rec. S4781-84 (1992). 
there is no possibility of grounding any right among U.S. legal system in International Covenant on Civil and Political Rights.

The possibility of grounding a judge's objection in the Universal Declaration of Human Rights as international custom is much more complicated. Since the 1900 U.S. Supreme Court Paquete Habana case ${ }^{38}$ international customs were incorporated into the U.S. domestic legal system. However, in the late 1990s, scepticism about automatic incorporation of customary law into the U.S. legal system started to be presented among U.S. legal scholars. ${ }^{39}$ The U.S. Supreme Court in Sosa v. Alvarez Machain case from 2004 has presented a much more detailed and specific view than just simple monism. ${ }^{40}$ The key issue is which norms are included in the concept of "law of nations", whose violation for a tort gives U.S. district courts jurisdiction. ${ }^{41}$ P. R. Dubinsky claims: "According to the Sosa majority much that is at the cutting edge of contemporary human rights law and international environmental law may fall outside the boundaries of the "law of nations"". ${ }^{2}$ Thus, since the binding force of customary law in U.S. legal system is extremely detailed and complicated, regarding the proper legal basis for the application of judge's objection in the Universal Declaration of Human Rights, which is an international custom, it is extremely uncertain.

Therefore, in spite of the fact that human rights treaties seem to guarantee judicial conscience clause, the only certain basis for its application might be found under U.S. domestic law.

\subsection{Judicial disqualification}

Thus, U.S. domestic law should be analyzed in order to find the proper legal basis for the application of a judicial conscience clause. Also, the derivation of a concrete exemption as a judge's conscientious objection from general philosophical principles might be implausible for some. Most accommodations, which allow one not to fulfil some obligation, are prescribed by statutory law with strict premises of applying boundaries

38 Paquete Habana, 175 U.S. 677, 700 (1900).

39 P. R. Dubinsky, op. cit., p. 465.

40 Sosa v. Alvarez Machain, 542 U.S. 692 (2004).

41 Alien Tort Statute, 28 U.S.C., section 1350.

42 P. R. Dubinsky, op. cit., p. 466. 
and exclusions. Here, the author proposes following up this idea and taking advantage of the valid legal institution: the disqualification of judge, which is present in every legal system with similar premises. However, the author believes that the justification of a judge's conscientious objection is a matter of more critical and theoretical inquiry than just positive law dogma. Therefore, the analysis of judicial disqualification, especially judicial recusal, is meant only as an analysis of the legal basis for the application of objection, not the legitimization of the judge's conscientious objection itself. Judicial disqualification includes two rules. While the first involves several strict premises for the disqualification of judge-like situations where the case involves a judge's interests, the judge is a relative of a litigant etc, the second concerns a less strict and more general situation of some lack of impartiality. The next part of this paper will be based on U.S. legal regulations concerning judicial disqualification and its interpretation given by U.S. courts and legal scholars. There are two reasons for such a choice. Firstly, the U.S. Constitution and whole legal system provides strong protection of individual rights, including the freedom of religion and conscience. Secondly, the U.S. social reality with its numerous religions and cultural beliefs has given a strong basis for developing the understanding of the freedom of religion and conscience. It has led to a broad analysis of many legal issues involving cultural or religious beliefs, which is not present to such an extent in the European legal tradition. With regard to judicial disqualification, the U.S. Federal Code (Judicial Code) provides in paragraph 455a:

(a) Any justice, judge, or magistrate judge of the United States shall disqualify himself in any proceeding in which his impartiality might reasonably be questioned.

(b) He shall also disqualify himself in the following circumstances:

(1) Where he has a personal bias or prejudice concerning a party, or personal knowledge of disputed evidentiary facts concerning the proceeding. ${ }^{43}$

At first glance, section (b) point (1) seems to be a good basis for the application of judicial objection. It requires personal bias or prejudice concerning a party for judicial recusal. However, firstly, formal proof is needed here, which could be difficult. Moreover, the formulation of this premise as a bias or prejudice concerning a party casts many doubts. If 
a judge is unwilling to reach a decision in a case in virtue of the case itself, not a party, is it really a bias or prejudice, and moreover, is it bias or prejudice concerning a party? Under U.S. cases and the legal interpretation, a positive answer can be given. Consider the statement from the Liteky case:

Bias and prejudice [are] not divided into the "personal" kind, which is offensive, and the official kind, which is perfectly all right.... It is common to speak of "personal bias" or "personal prejudice" without meaning the adjective to do anything except emphasize the idiosyncratic nature of bias and prejudice.... In a similar vein, one speaks of an individual's "personal preference" without implying that he could also have a nonpersonal preference. ${ }^{44}$

The author does not share such a point of view. It may be true in a situation when a party is a member of some group disliked by a judge. A judge may not have a prejudice to a party itself, his prejudice is grounded in the fact that this party is a member of a group. However, in the question on judicial conscientious objection presented in this paper, a judge can be seen as biased to a case as he is unwilling to decide it, not to a party. The author believes that only some functional broadening interpretation can rescue such a view. This is present in 1892 Logan Supreme Court ruling, where it is said:

A juror who has conscientious scruples on any subject, which prevent him from standing indifferent between the government and the accused, and from trying the case according to the law and the evidence, is not an impartial juror. ${ }^{45}$

The Logan case involved a juror having conscientious scruples in regard to the infliction of the death penalty for a crime, not a judge. However this may be taken into consideration in understanding the U.S. Supreme Court views on bias. Still, under paragraph 455 a subsection (b) point (1) a formal proof is required to disqualify a judge.

Thus, subsection (a) is more amenable to taking advantage of, since it requires just a situation when impartiality might reasonably be questioned. This provision says that a judge should recuse himself from deciding on a case where circumstances might put into question his impartiality. Many procedural codes all over the world provide identical or similar

44 Liteky v. United States, 510 U.S. (1994), p. 549.

45 Logan v. United States, 144 U.S. (1892), pp. 263, 292. 
regulations. It is clear that a judge can be partial to one of the litigants, however can he be partial not to a person but to a case itself? Only the latter would lead to the possibility of taking advantage of judicial recusal as a valid legal ground for a judge's conscientious objection unless we accept the broadening of the meaning of prejudice. For instance, Justice Scalia equated the traditional/due process meaning of impartiality to "lack of bias for or against either party to the proceeding" ${ }^{46}$. He seems to regard impartiality only as a bias concerning the party, not the case itself. As one may notice, the concept of impartiality has been explained by Justice Scalia within the situation of a bias. It is indeed the main fashion of analyzing among jurists what impartiality is. In the next part I will present some cases as well as doctrinal views on what bias is and whether cultural or religious bias can result in a situation of judge's impartiality leading to his recusal.

\subsection{Cultural or religious bias}

Paragraph 455a received its contemporary meaning in 1974 after having been completely rewritten. ${ }^{47}$ The first case where under new regulations a claim for judge's recusal occurred based on religious matters was the 1979 case Idaho vs Freeman. ${ }^{48}$ In this case, the plaintiffs challenged congressional authority to extend the ratification deadline for the proposed Equal Rights Amendment (ERA), and sought to validate Idaho's rescission of its prior approval of the ERA. ${ }^{49}$ On 8.8.1979, the Justice Department, representing the defendant, filed a motion to disqualify Judge Marion Callister from hearing the case. The defendant contended that because Judge Callister held a prominent position within the Church of Jesus Christ of Latter-day Saints (Mormons), which officially opposes both the ERA and the extension of its ratification deadline, there existed

46 Republican Part of Minnesota vs White, 536 U.S. p. 770 (quoting Minnesota Code of Judicial Conduct) Canon 5(A)(3)(d)(i) (2002). cited from: M. Jones, Religiously Devout Judges: A Decision-Making Framework for Judicial Disqualification, 'Indiana Law Journal' 2013, vol. 88, no. 3., p. 1089, p. 1096.

47 G. Burkhardt, Idaho v. Freeman - Judicial Disqualification: The Effect of Religious Leadership on Judicial Impartiality, 'The John Marshall Law Review' 1980, vol. 14, no. 1, p. 243 , p. 244.

48 State of Idaho v. Freeman, 529 F. Supp. 1107 Idaho (1981); G. Burkhardt, op. cit., p. 246.

49 G. Burkhardt, op. cit., p. 246. 
a reasonable basis to conclude that his ability to impartially consider the action might be or appear to be impaired. ${ }^{50}$ In a brief overview of the law of disqualification, Judge Callister noted that the test under section 455(a) was not the subjective belief of the defendant or the judge, but whether the facts would lead a reasonable person to infer that bias or prejudice existed. ${ }^{51}$ No appeal has been taken from judge's decisions. Analyzing this issue, Gwenda M. Burkhardt states:

Despite Judge Callister's tenuous reasoning, his decision is supportable if the consequences of granting the disqualification motion are examined. If section 455(a) required disqualification based on religious affiliations, Catholics would be proscribed from presiding over abortion cases and Jews would be proscribed from presiding over prosecutions for violating Sunday closing laws. ${ }^{52}$

Although it may be true under the litigant's claim for disqualification, it does not lead to the collapse of the idea of a judge's conscientious objection. In the latter, it is only the judge who has the right not to reach a decision in a case when it is in conflict with his moral beliefs. When he is objectively a member of a group with some moral requirements but is mentally able to decide impartially, there is no conflict of the case and his conscience. Thus, in a situation without a conflict between legal duty and conscience analyzing, conscientious objection has no grounds. This is however not the case when a judge feels that his beliefs and a case are in conflict.

Among U.S. legal thought, there are papers analyzing the judicial bias that focus on racial, gender, regional and other roots of bias with very little examination of cultural or religious grounds itself as foundations of bias. ${ }^{53}$ Even if someone considers deep world-view beliefs of a judge as grounds for disqualification, it is undertaken mainly from a litigant's perspective and his right to a fair trial while the perspective of a judge and his conscientious conflict plays a secondary role. ${ }^{54}$ However, this is

50 G. Burkhardt, op. cit., p. 247.

51 G. Burkhardt, op. cit., p. 251.

52 G. Burkhardt, op. cit., pp. 258-259.

53 S. Bloom, Judicial Bias and Financial Interest as Grounds for Disqualification of Federal Judges, 'Case Western Reserve Law Review' 1980, vol. 35, no. 4, p. 662; D. Nugent, Judicial Bias, 'Cleveland State Law Review' 1994, vol. 42 no. 1, p. 1; D. Ban, Making Appearances Matter: Recusal and the Appearance of Bias, 'BYU Law Review' 2011, no. 4, p. 943.

54 M. Jones, op. cit.; A. Barrett, J. Garvey, Catholic Judges in Capital Cases, 'Notre Dame Law School Scholarly Workshop' 1998, Paper 527, p. 303. 
not the same situation not only from a personal point of view, but also objectively. There is a possibility of a case being heard where a judge who has not been sharing his religious beliefs or even membership of a church or other group should reach a decision in a case which is in conflict with his conscience. In such a situation, neither the litigants, nor public opinion has any information on the possibility of his being biased. It is only the judge himself who is aware that his beliefs are in conflict with the case. Thus, also from the party's perspective, it is only judge who is able to maintain impartiality by recusing himself.

Despite broad discussion among legal scholars on the premises of judicial disqualification and some analysis of the definition of bias, the role of the religious roots of bias etc., there has been no consideration whether a judge as an individual person has the right to recuse himself from the case when the case involves conflict with his beliefs. For the judge's conscience clause, the core issue is whether a judge's beliefs can violate the principle of partiality making him impartial when he is not partial to a party but simply does not want to make a decision in a concrete case. This is not prejudged among the statements I have found. Moreover, it is highly unlikely to be analyzed from the point of view which is presented in this paper, that is from the point of view of a judge himself as an individual having his own religious or cultural beliefs. No U.S. court judgements formulate the right to a judge's conscientious objection. In such a case, there is a place for one's own thoughts. I would like to firmly stress that the following conclusions are based on the author's interpretation, without founding them on a clear disposition of statutory law or a precedent. I believe that bias based on religion or culture may lead to impartiality in the legal sense of this term, as for instance to a situation when a judge would be more likely to reach a decision in a case in accordance with his conscience as close as it is possible. In such a situation it is better for the parties that this judge not reach a decision in this case. Moreover, it is better for a judge himself not to decide it, as he could maintain his conscience in peace. That is the point of this paper. Thus, the regulation of judicial disqualification can be the legal basis for taking advantage of a judge's conscientious objection.

It is possible to indicate U.S. Supreme Court Garcetti vs. Ceballos precedent claiming that "when public employees make statements pursuant to their official duties, they are not speaking as citizens for First Amendment purposes, and the Constitution does not insulate their 
communications from employer discipline". ${ }^{55}$ The case involved the alleged violation of the First Amendment by the head of Los Angeles County District Attorney's Office who passed up for a promotion a district attorney, who claimed that this took place due to his criticizing of the legitimacy of a warrant. The U.S. Supreme Court stated that the district attorney made a statement concerning public duties, and thus, the constitutional freedom of speech is not guaranteed in this case. It may be disputable whether this precedent would be binding in a case concerning a judge's conscientious objection. Firstly, Garcetti vs. Ceballos involved freedom of speech, conscientious objection might be however classified as freedom of religion. Secondly, the facts of Garcetti vs. Ceballos might greatly differ from the facts of a possible future case involving a judge taking advantage of conscientious objection. For these two reasons, The author doubts that Garcetti vs. Ceballos might be binding in the case of a judge who would take advantage of objection. Nonetheless, such a ruling should be pointed out. The author believes that Garcetti vs. Ceballos should not play a decisive role in the analysis of judge's conscience clause. However, in practice, the standard of protection of a judge's freedom of religion might be lesser than the standard of protection of other U.S. citizens rights.

\section{Conclusions}

Assuming that Garcetti vs. Ceballos is not regarded as the binding precedent in this analysis, all things considered, both philosophical and legal, a judge has the right to conscientious objection. Its philosophical justification has been analyzed and proved in section 2 . The legal basis for its application can be found in the regulations of judicial disqualification where the concept of impartiality is understood as not only simply being partial to a party in litigation, but also as a lack of bias, prejudice and reluctance to the case itself. Despite the fact that positive law may not explicitly introduce such a right, with the assistance of legal interpretation we can conclude that the judge's right to conscientious objection is included in his right to recusal. Thus, the judge's conscientious clause can be seen as a valid legal rule. However, taking into consideration Garcetti vs. Ceballos and the idea underlying this U.S. Supreme Court ruling, the above conclusions

Garcetti v. Ceballos, 547 U.S. 410 (2006), at p. 1. 
should be undertaken more carefully, in a more hypothetical form. Whether this case should be taken into consideration or not is a matter of predicting a hypothetical U.S. court case involving a judge's conscientious objection and previous judgements, and which court would like to apply. I am not able to directly answer this question, nonetheless, I would like to emphasize that the U.S. courts might regard the scope of a judge's freedom of religion lesser than other citizens. As a result, they would not regard the right to a judge's conscientious objection as a valid legal rule. However, I present an opposing point of view.

One must not forget about the philosophical premises of the justifiability of this exemption, especially the last three where factual issues, different in every society, play the most important role. Moreover, the boundaries of the application of a judge's conscientious objection must be preserved, maintaining the individual right to reach a decision in his case by tribunal, also in factual terms.

Allowing a judge to possess a conscience clause should also be considered in light of statutory regulation of judicial disqualification and the principle of impartiality. From a historical point of view, the scope of situations when a judge should not reach a decision in a case has broadened. M. Jones writes:

In 1792, the federal government enacted legislation that simply codified the common law-including disqualification for district judges who were "concerned in interest" (referring to financial conflicts of interest), as well as those who had served as counsel for either party. ${ }^{56}$

This is the very first regulation of judicial disqualification. We can see how narrow its scope was at the end of $18^{\text {th }}$ century. She further claims that at the beginning of $20^{\text {th }}$ century, bias as a demand for disqualification was extremely unlikely. ${ }^{57}$ It was a long way to introduce a situation of bias as a premise for disqualification. After some time, several internal ethical regulations were implemented. In 1995, the U.S. Supreme Court described a standard of 'fair tribunal' as lacking both objective bias and subjective bias. ${ }^{58}$ Today's meaning of a regulation with 'impartiality might reasonably

56 M. Jones, op. cit., p. 1092.

57 M. Jones, op. cit., p. 1092.

58 See M. Jones, op. cit., p. 1094. According to the Supreme Court, "a fair trial in a fair tribunal is a basic requirement of due process. [...] Our system of law has always 
be questioned' stems from 1972. The judicial conscience clause can be seen as the next broadening of the scope of judicial disqualification: it allows for a judge not to reach a decision in a case when it is contradictory to his deep cultural or religious beliefs. This can take place without any public knowledge of this fact. If we add the duty to take advantage of the clause by recusing himself, not controversial I suppose, we receive a new broadening of the regulation of judicial disqualification. And this is the next step in protecting an individual's right to a fair trial by an independent and impartial tribunal, which is one of the basic human rights. ${ }^{59}$

\section{Bibliography}

1. Ban D., Making Appearances Matter: Recusal and the Appearance of Bias, 'BYU Law Review' 2011, vol. 2011, no. 4.

2. Barrett A., Garvey J., Catholic Judges in Capital Cases, 'Notre Dame Law School Scholarly Workshop' 1998, Paper 527.

3. Bloom S., Judicial Bias and Financial Interest as Grounds for Disqualification of Federal Judges, 'Case Western Reserve Law Review' 1980, vol. 35, no. 4.

4. Bou-Habib P., A Theory of Religious Accommodation, 'Journal of Applied Philosophy' 2006, vol. 23, no. 1.

5. Burkhardt G., Idaho v. Freeman - Judicial Disqualification: The Effect of Religious Leadership on Judicial Impartiality, 'The John Marshall Law Review' 1980, vol. 14, no. 1.

6. $\quad$ Ciszewski W., Wyłączenia światopoglądowe jako przedmiot dyskusji teoretycznej - próba systematyzacji, 'Forum Prawnicze' 2016, vol. 34, no. 2.

7. Collins M., Conscience Clause and Oral Contraceptives: Conscientious Objection or Calculated Obstruction?, 'Annals of Health Law' 2006, vol. 15, no. 1.

8. Dubinsky P. R., International Law in the Legal System of United States, 'The American Journal of Comparative Law', vol. 58, Supplement: Welcoming the World: U. S. National Reports to the XVIIIth International Congress of Comparative Law 2010.

endeavored to prevent even the probability of unfairness. [...] Such a stringent rule may sometimes bar trial by judges who have no actual bias and who would do their very best to weigh the scales of justice equally between contending parties. But to perform its high function in the best way "justice must satisfy the appearance of justice" (In re Murchison, 349 U.S. (1955), p. 133, 136).

59 Universal Declaration of Human Rights, 1948, Article 10; European Convention on Human Rights, 1950, Article 6; International Covenant on Civil and Political Rights, 1966, Article 14. 
9. Dworkin R., Taking Rights Seriously, Harvard University Press, London 1977.

10. Flynn D., Pharmacists conscience clause and access to oral contraceptives, 'Journal of Medical Ethics' 2009, vol. 34, no. 7.

11. Humphrey J. P., The Universal Declaration of Human Rights: Its History, Impact and Juridical Character [in:], B. G. Ramcharan (ed.), 'Human Rights: Thirty Years After the Universal Declaration', Kluwer, The Hague-Boston-London 1979.

12. Jones M., Religiously Devout Judges: A Decision-Making Framework for Judicial Disqualification, 'Indiana Law Journal' 2013, vol. 88, no. 3.

13. Levy J., The Multiculturalism of Fear, Oxford University Press, Oxford 2000.

14. Miller J., The Unconscionability of Conscience Clause: Pharmacists' Conscience and Women's Access to Contraception, 'Health Matrix: The Journal of LawMedicine' 2006, vol. 16, no. 1.

15. Nugent D., Judicial Bias, 'Cleveland State Law Review' 1994, vol. 42 no. 1.

16. Postema G., Legal Philosophy in the Twentieth Century: The Common Law World, 'A Treatise of Legal Philosophy and General Jurisprudence', vol.11, Springer, Dodrecht, Heidelberg, London, New York 2011.

17. Quong J., Cultural Exemptions, Expansive Tastes and Equal Opportunities, 'Journal of Applied Philosophy' 2006, vol. 23, no. 1.

18. Stempel J., Chief William's Ghost: The Problematic Persistence of the Duty to Sit Doctrine, 'Scholarly Works' 2009, Paper 232.

19. Vallier K., The Moral Basis of Religious Exemptions, 'Law and Philosophy' 2016, vol. 35, no. 1.

20. Waldron J., One Law for All? The Logic of Cultural Accommodation, 'Washington and Lee Law Review' 2002, vol. 59, no. 1.

21. Zajadło J., Nieposłuszeństwo sędziowskie, 'Państwo i Prawo', 2016, no. 1. 